\title{
EXAMING CURRENT PROVISION, PRACTICE AND EXPERIENCE OF INITIAL TEACHER TRAINING PROVIDERS IN IRELAND PREPARING PRE SERVICE TEACHERS FOR THE INCLUSION OF STUDENTS WITH SPECIAL EDUCATION NEEDS IN PHYSICAL EDUCATION CLASSES Susan Crawford *', R O'Reilly * N Flanagan *
}

\author{
* Sports Studies and Physical Education, University College Cork, Ireland
}

\begin{abstract}
Research from an international perspective in relation to the preparation of pre service teachers in physical education and special educational needs indicates that initial teacher training providers are inconsistent in the amount of time spent addressing the issue and the nature of curricular content (Vickerman, 2007). In Ireland, research of Meegan and MacPhail (2005) and Crawford (2011) indicates that physical education teachers do not feel adequately prepared to accommodate students with Special Educational Needs (SEN) in physical education classes. This study examined initial teacher training provision in Ireland in the training of pre service physical education teachers in SEN. The methodology used was qualitative and included questionnaires and interviews $(n=4)$. Findings indicated that time allocation (semester long modules), working with children with disabilities in mainstream settings (school or leisure centre based), lack of collaboration with other PETE providers $(n=4)$ and a need for continued professional development were themes in need of address. Using a combined approach where the recently designed European Inclusive Physical Education Training (Kudlácěk, Jesina, \& Flanagan, 2010) model is infused through the undergraduate degree programme is proposed. Further, the accommodation of hands on experience for undergraduates in mainstream settings and the establishment of inter institutional communities of practice, with a national disability research initiative, is essential to ensure quality adapted physical activity training can be accommodated throughout Ireland.
\end{abstract}

Key Words: Initial teacher training, physical education, Special Educational Needs, Inclusion Word Count: 199

\section{INTRODUCTION}

The traditional pattern of education in Ireland like many nations around the world involved mainstream education and special education running parallel to one another. This dualist division of education, inter alia contributed to the isolation of students with special educational needs (SEN) from their peers without SEN. However, philosophies regarding the education of children with special educational needs have changed significantly over the past two decades. Unvaryingly research studies worldwide are revealing that students with special educational needs are increasingly been educated alongside their peers who do not have SEN (Shevlin \& O’Moore, 2000; Block
\& Obrusnikova, 2007; Klavina, Block, Larins, et al, 2007; Xafopoulos, Kudláček, Evaggelinou et al, 2009; Vickerman \& Coates, 2009). Today, the policy of inclusion is now the central tenet of basic education policy globally (Gita, Bognar, Kalbli, Laszlo,et al, 2008). The role of the teacher as a facilitator of inclusion and as a manager of the inclusive educational environment is vital (Morley, Bailey, Tan, \& Cooke, 2005). Many authors have researched the perspectives of qualified PE teachers regarding inclusion and what is obvious within these studies is that the issues of concern today for PE teachers are effectively the concerns expressed throughout the last 20 years. Back in 1999, Folsom et al 
noted that not preparing physical educators to teach and work with individuals of all abilities was a serious error of omission in initial teacher training physical education programmes. Much research previous to and since then would seem to support this statement, as several studies identified that PE teachers believe they are inadequately prepared to effectively teach students with SEN and feel a lack of perceived readiness and support to include students with SEN satisfactorily (Depauw \& GocKarp, 1994, LaMaster et al., 1998, Lienert et al, 2001, Hodge et al, 2004, Klavina et al., 2007, Vickerman \& Coates, 2009).

Kozub et al (1999) suggests that teacher training has as a large impact on how future physical education teachers develop their knowledge of disabilities and their understanding of differences in students. Kozub continues that the effective preparation of teachers is essential to the outcome and quality of education received by students with SEN. In fact, if teachers are deprived of opportunities to develop skills for working with students with disabilities, these students may be denied equal access to education (Vickerman \& Coates, 2009, Hardin, 2005). Given these identified and established difficulties for physical education teachers and consequently for students with SEN, it was deemed necessary to examine provision, practice and experience of Initial Teacher Training Physical Education Provision (ITTPE) in Ireland, in relation to accommodating children with special educational needs, as this has not been documented previously.

\section{PHYSICAL EDUCATION TEACHER EDUCATION (PETE)}

The need to address initial teacher training provision is justified on the basis that international research identifies initial teacher training providers of physical education as the key players in connecting international policies on inclusion with the practice of physical education teachers on the ground. (Block 2007; Smith \& Green, 2004; Vickerman, 2007). DePauw and Doll-Tepper
(2000) and Morley, Bailey, Tan \& Cook (2005) further indicate that addressing inclusive practices at undergraduate level will ensure students with SEN receive quality PE programmes. However, Avramadis and Norwich state that $(2002$, p. 139) 'without a coherent plan for teacher training in the educational needs of children with SEN, attempts to include these children in the mainstream would be difficult'.

Much research internationally has provided us with results from studies which looked at various aspects of ITTPE and what impact these have had on the pre-service teachers. Hodge and Jansma (1999) and Hodge et al, (2002) compared on-campus and off-campus practicum's and their impact on attitude change of PETE students. Results from both studies were contradictory. Hodge and Jansma's (1999) study found that on-campus practicum experiences had a significantly greater impact on attitude change whereas the Hodge et al study found no significant difference between the two practicum types. Vickerman and Coates (2009) looked at trainee PE teachers (202) and recently qualified PE teachers (19) and found that both groups identified their initial teacher training had not prepared them sufficiently to work with children with SEN in schools.

As far back as 1994, DePauw and Goc Karp (1994) identified the infusion model as a means of addressing this issue for future PE teachers. Vickerman (2007) stated that a means of addressing ITT in relation to PE providers was that of adopting an "Eight $\mathrm{P}$ Inclusive Framework". Vickerman identified these as ensuring preservice teachers understand the philosophy of inclusion, ITT providers should embrace a purposeful approach, Further

Teacher trainers need to be proactive in the development and implementation of inclusive $P E$ and consult actively with schools, experienced PE teachers, schools, mentors and children with SEN in order to produce a partnership approach to inclusive $P E$ (Vickerman, 2007, p.15). 
Inclusive PE is also identified as an evolving process including input from key stakeholders. ITT PE providers must also ensure policy documents reflect their commitment to inclusion. Implementation of effective pedagogical practices is also essential for ITT providers, pre service teachers, qualified teachers and other facilitators in the field. Finally the culmination of successful inclusion in PE is that of the training impact of practice for the child with SEN. In Europe, the initial development in adapted physical activity saw the establishment of The European Federation of Adapted Physical Activity (EUFAPA) in the eighties. This organisation is concerned with

"The promotion and dissemination of experiences, results and findings in the fields of adapted physical activity and sport science and their practical application to the benefit of individuals across the life span."

A further development in APA in Europe is that of the establishment of The European Standards in Adapted Physical Activity (2010) which aimed to contribute to more social inclusion by setting up the standards for training professionals who will be responsible for inclusion in the areas of physical activities. The project presented a theoretical framework of professional competencies needed by those working in the area of APA. Contributors to EUSAPA identify the need to consider the development of the role of Adapted Physical Education Specialists as exists in the United States. However, in the current climate of European Economic recession this is highly unlikely. Meanwhile, the European Inclusive Physical Education Training, EIPET (Kudlácěk, Jesina, \& Flanagan, 2010) has been designed to address emerging needs of ITT PE Provision and is readily available to all PETE providers. Aims of the EIPET project $(2010$, p.2) are:

(a) To transfer the innovative model at the Institute of Technology, Tralee (ITT), Ireland of teaching inclusive physical education to partner organisations in initial and continued vocational training, thus improving the quality and volume of cooperation between institutions in Europe; (b) To critically examine and adapt the inclusive physical education training module in ITT with the guidance of internationally acclaimed partner organisations and associated APA network contacts; (c) To progress towards the Education and Training work programme 2010 priority areas through; advancing peer learning activities, facilitating the development of innovative practices, promoting excellence and equal opportunities, enabling learning to cater for rapidly changing work environments, and enabling efficiency and equity in education and training systems; (d) To empower teacher training providers and PE teachers with the knowledge, skills and competence to operate effectively in the work environment; (e) To facilitate equity of opportunity in Physical Education for all; (f) To develop a resource pack to accompany the model and modules and make it available for download from the project website (www.eipet.eu) or available on $\mathrm{CD}$.

This development very clearly embraces theoretical content and hands on praxis based on a successful example of good practice.

\section{Physical Education Teacher Education and SEN in the Irish Context}

This section outlines official educational policy in relation to Teacher Education, specifically physical education teacher education and Special Educational Needs in Ireland. For the purpose of this study the term "special educational needs (SEN) has been adopted as per the current practice in Ireland. Special educational needs in this context include students with disabilities. "In relation to SEN, this refers to around one in five children who have a learning difficulty that requires specific action by the school and encompasses a diverse range of social, emotional, behavioural, cognitive, learning and physical needs" (Vickerman, 2007, p. 386). In Ireland, The Education for Persons with Special Educational Needs Act, (2004, p. 5) defines Special Educational Needs as: "Those students having a restriction in their 
capacity to participate in and benefit from education on account of an enduring physical, sensory, mental health or learning disability, or any other condition which results in a student learning differently from people who do not have the condition."

International policies that have affected the provision for children with SEN include the United Nations Convention on the Rights of the Child (1989), the UN Standard Rules on the Equalisation of Opportunities for Persons with Disabilities (1993) and the United Nations Educational, Scientific and Cultural Organisation (UNESCO) Salamanca Statement (1994). The Salamanca Statement (1994) has been particularly instrumental in addressing the issue of mainstreaming of children with SEN.

On a national level, policies in Ireland that address developments for individuals with SEN include the Special Education Review Committee (SERC) Report (1993), the Report of the Government Commission on the Status of People with Disabilities (1996), the National Council for Curriculum and Assessment (NCCA) discussion document (1999), the Education Act (1998), the Equal Status Act (2000) and the Education for Persons with Disabilities Act (2004). The Education for Persons with Special Educational Needs Act (EPSEN) was introduced in Ireland in 2004 but of yet has not been legally enacted.

The Teaching Council of Ireland (2007, p.7) identify social justice, equality and inclusion as one of the core values of the teaching profession stating

Teachers in their professional role show commitment to democracy, social justice, equality and inclusion. They encourage active citizenship and support students in thinking critically about significant social issues, in valuing and accommodating diversity and in responding appropriately.

In relation to student potential, the Teaching Council (2007, p.7) further identifies that

Teachers recognise the individual potential of students. They know that those with special/exceptional needs and potential require access to appropriate expertise and resources in the context of a whole school approach.

The regulations for registration of the Teaching Council (2009, p.20) indicate that Newly qualified teachers must have fulfilled inclusion and diversity, meeting diverse needs including children with Special Educational Needs, educational disadvantage and intercultural education.

The National Council for Special Education (NCSE) was set up to improve the delivery of education services to persons with Special Educational Needs with particular emphasis on children. The Council was first established as an independent statutory body by order of the Minister for Education and Science in December 2003. The council provides support and resources for schools while also developing collaborative links with the Department of Health and Children and other relevant sectors. With regard to the EPSEN Act (2004) the NCSE indicates that the implementation of key sections which confers statutory rights to assessment, education plans and appeals processes on children with SEN has been deferred due to the current economic circumstances.

In accordance with the Department of Education and Skills (DES) and the Teaching Council's framework document (2009) it is incumbent on initial teacher training providers to collaborate with relevant personnel to ensure future PE teachers will have the necessary skills to promote quality $\mathrm{PE}$ provision for students with SEN. The revised junior cycle PE curriculum (NCCA, 2003, p.6) states that

Schools should facilitate as far as possible the inclusion of students with disabilities in all physical education activities.

It further states that PE syllabi

Underline the principle of inclusion and should subscribe to the basic goals of meeting the needs of all students.

The Junior Cycle Physical Education Support Service (JCPESS) website, whose aim is to 
provide on-going support and professional development for all junior cycle physical education teachers, provides no specific guidelines or framework for the accommodation of students with SEN in PE. The Physical Education Association of Ireland (PEAI), which is the professional association for PE teachers lists "inclusivity" as one of its core values in its strategic plan which states "physical education should be open to all regardless of ability".

In Ireland, the Teacher Education Section (TES) of the Department of Education and Skills is responsible for approving undergraduate and higher diploma courses for teachers in PE. The NCCA is the agency responsible for the design of each subject syllabus and the Inspectorate is responsible for evaluating the quality and provision of teaching and learning in the delivery of each of these syllabi. The Inspectorate is also responsible for evaluating the organization and quality of school management, deployment of allocated resources and support for students, including those with disabilities (PE Inspectorate, Department of Education and Science, 2006). In Ireland, there are four third-level institutions providing PETE to degree level. Traditionally in the Irish context, PE graduates work within the post primary school sector. However, PE graduates can also be employed in a part-time capacity ( 2 hours/week) in special school settings, as special schools also cater for children of secondary school age, up to the age of 18 years. PE teachers have indicated that the PE undergraduate training is inadequate, with regard to preparing $\mathrm{PE}$ teachers working with children with SEN (Crawford, 2011, Department of Education and Science, 1999; House of the Oireachtas, 2005; Meegan and MacPhail, 2006). In 2002, the PEAI indicated that $84 \%$ of PE teachers had not attended inservice training in the area of adaptation of physical activity for children with SEN. Clearly, there is a lack of information on the delivery of APA modules at undergraduate level by initial PETE providers.
Hence, the purpose of this study was to qualitatively examine the provision, practice and experience of the four identified physical education initial teacher training institutes in Ireland in the training of pre service physical education teachers to accommodate students with special educational needs in physical education classes.

\section{METHODOLOGY Participants}

Lecturers at the identified PETE institutes $(n=4)$ with responsibility for the delivery of adapted physical activity modules were invited to participate in the study. Participants were formally informed of the purpose and methodology of the study as well as the nature and extent of their participation. Participation was voluntary. Inclusion criteria were that of being the identified facilitator of APA. Respondents' ages ranged from 30 to 46 years. Out of the four participants, three were lecturers with the fourth describing the job title as Assistant lecturer and Co-ordinator of APA. One respondent completed a $\mathrm{PhD}$ in SEN and specifically Motor Impairment and Autistic Spectrum Disorders. A second respondent attained a Masters in APA and furthermore completed a $\mathrm{PhD}$ on inclusion in PE for children with SEN. A third respondent had a PhD in Sport Pedagogy with a minor emphasis on Movement Studies in Disability. The fourth respondent had a primary degree in Sport and Exercise Science, a Master's thesis in Sports Science but did not have a post graduate speciality in APA. All respondents described varying degrees of practical experience in special educational needs prior to taking up their respective posts; some of this experience was part of their academic preparation, some in employment whilst the remainder was voluntarily gained.

\section{Procedures}

Qualitative research included postal questionnaires and follow up interviews. These data collection methods of choice embraced the idea of developing on general themes identified in questionnaires and addressed in greater depth with interview. 
Further, the chosen research methodology embraced the objectives of credibility, dependability and conformability (Vickerman, 2007). (1) The questionnaire was adapted from that of Vickerman (2004) which was specifically designed for examining issues of Special Educational Needs Provision in PETE Institutions in the U.K, and was initially piloted with ten lecturers in UK Universities. Vickerman's questionnaire has established reliability and validity for this purpose (Vickerman, 2004). Adaptations to the questionnaire for the current study included minor text changes to accommodate official and educational differences that exist in Ireland i.e. the Irish educational system only employs physical education graduates to work in secondary school settings. Physical education for primary school children is delivered by primary school teachers and the wording was changed accordingly.

(2) Follow up semi structured interviews followed that of the quality criteria for good interviewing practice as outlined by Kvale and Brinkmann (2009). These included the extent of spontaneous and relevant answers from the interviewee, the extent of short interviewer answers, the degree to which the interviewer followed up and clarified meanings of relevant aspects, the interview being interrupted, the interviewer verifying interpretations of subject's answers and the interview being "self reported". These researchers further identified that the interviewer should be knowledgeable, structuring, clear, gentle, sensitive, open, steering, critical, remembering and interpreting.

As per the research methodology of Vickerman (2004) and Moore (2000) key themes and issues for interview were identified from the questionnaire. These included details obtained in relation to respondents training and experience, how they managed and coordinated modules, the content and delivery of programmes, how they established links with schools and mentors, details of their own values and attitudes and finally if there was anything further they wished to highlight in relation to APA provision and practice. The four taped and transcribed interviews were coded from A-D to preserve confidentiality.

\section{Sources of Data}

Data was generated from the two sources. Questionnaires were completed and dealt with the following themes: about you; about your institution; management and coordination of SEN; programme content and delivery; links with schools and mentors; partnerships with disability sport/special needs agencies; values and attitudes; and other views and opinions. Follow up interviews were conducted on receipt and analysis of the completed questionnaires. Interviews were tape recorded, transcribed and coded.

\section{Data Analysis}

Findings from the questionnaire were inputted into SPSS Version 16 for descriptive statistical analysis. Member checks were used to ensure credibility of findings of interviews (Creswell, 2007; Denzin, 1989; Erickson, 1986). Comparing and cross checking of both key sources of evidence was carried out. Credibility was achieved through involvement with the respondents, confidentiality of respondents and public presentation of data evidence. Dependability of the study's research processes were systematic, clearly evidenced and rigorous to be subject to external scrutiny. Conformability of the research design enables researchers the opportunity to follow and replicate the chosen methodology within a systematic design structure.

\section{Results and Discussion}

Results and discussion were analysed around the key areas addressed in the questionnaire and follow up interviews. As previously outlined these included examination of respondents training, experience and practice of APA in their institute; management and coordination of SEN; Programme content and delivery; links with schools and mentors including partnerships with disability sport and special needs agencies; values and 
attitudes and finally scope for further comments.

About you; about your institution
Three of the institutions were universities and one was an institute of technology. The table below relates the number of students, postgraduates and lecturers per institution.

Table 1: Numbers of students and lecturers in Irish Institutions

\begin{tabular}{|l|c|c|c|}
\hline & $\begin{array}{l}\text { No. of } \\
\text { Undergraduates }\end{array}$ & No. of Postgraduates & $\begin{array}{l}\text { No. of lecturers } \\
\text { delivering PE } \\
\text { teacher training }\end{array}$ \\
\hline $\begin{array}{l}\text { University College } \\
\text { Cork }\end{array}$ & 200 & 2 & 4 \\
\hline $\begin{array}{l}\text { Dublin City } \\
\text { University }\end{array}$ & 160 & 0 & 6 \\
\hline $\begin{array}{l}\text { Institute Of } \\
\text { Technology } \\
\text { Tralee }\end{array}$ & 32 & 0 & 3 \\
\hline $\begin{array}{l}\text { University of } \\
\text { Limerick }\end{array}$ & 280 & 24 & 12 \\
\hline
\end{tabular}

Table 1 provides details of the student and lecturer numbers in the four Irish PE Institutions, including those completing postgraduate study. Of these, the University of Limerick has the greatest number of undergraduates and post graduate students. The University of Limerick is also part of the Erasmus Mundus Consortium accommodating postgraduate study in APA. Hence, the ethos of post graduate research in APA is well established here. At University College Cork there are 200 undergraduates studying PE. Of the 2 postgraduates studying in the area of Sports Studies and Physical Education, one of these PhD students is specifically completing research in the area of PE and inclusion. In Dublin City University there are approximately 160 undergraduates. At the Institute of Technology Tralee, 32 students are studying PE. These students, having completed an initial three years BSc in Health and Leisure Studies degree, chose the PE option in their final year of studies. They will go on to complete their post graduate study in teacher education in the University of Limerick to meet the Teaching Council standards, as outlined earlier. Neither of these last 2 Institutes have postgraduate study in the area of APA. Staffing within each ITT PE providers vary in both numbers and subject specialities.

In the overview of respondents training and experience delineated within the methodology section, it is clear there is a vast array of expertise and skills among ITT PETE providers. However, respondents need to embrace Harford and MacRuairc's (2008) concept of developing communities of practice in teacher education in this instance in relation to APA development intra and inter institutionally. Within this context, the community of practice would entail the four institutions coming together as a group to share knowledge relating to inclusion. This concept was more recently recommended by Crawford, O'Reilly and Luttrell (2011) when examining reflective practice among pre service teachers in relation to APA delivery. This would provide each of these experts with an opportunity to showcase and develop their existing expertise firstly among their own colleagues and also with colleagues in other institutions. This type of collaboration is essential for the promotion of quality APA in the Irish context. 
Management and coordination of SEN throughout ITTPE curriculum

All of the four PETE providers appeared to have an identified person designated for the delivery of Adapted Physical Activity modules. One respondent stated:

Although I deliver the APA module, other staffs add in aspects of inclusive games to their modules in what appears an ad hoc sort of way. To date we haven't joined up in our approach to this across the degree programme, which is frustrating. Where I have suggested infusing the topic throughout the degree, it just hasn't been embraced in any meaningful way.

A second provider indicated while responsible for the management of APA modules the respondent wasn't sure to what extent other lecturers included aspects in their programmes:

I'm not entirely sure who else may be covering aspects of APA in their modules. The practical module in fourth year is coordinated by another staff member.

The third respondent indicated that while she is identified as the APA coordinator, a number of staff is involved in the management of APA for pre service PE students at her institute. None of the staff had formal post graduate qualifications in this area.

There is five staff covering aspects of APA in different modules. All of the PETE staff have mainstream qualifications but have completed National Governing Body training in Ireland and abroad in various sports and inclusion initiatives. We have also attended European and international conferences, study days and practical sessions. Further training has been obtained in aquatic rehabilitation and Halliwick foundation and advanced courses. Staffs have also completed Disability organisations training courses.

A fourth respondent indicated that she was specifically responsible for the coordination and management of APA: I am the only staff member with responsibility for APA management and delivery. I am also the only staff member with specific APA qualifications.

Management and coordination of SEN appears somewhat ad hoc in each of the Irish institutions. There is clearly a need for each ITT PE provider to establish exactly who if any other staff members are also involved in the delivery of APA and related topics of SEN throughout the degree programme. This then allows for joined up thinking as advocated by Vickerman (2007) to ensure the quality delivery of both theory and practice in relation to APA. Further, this would allow for the development of the infusion model of DePauw and Goc Karp (1994), where APA could be embraced over the four years of the degree programme. Undergraduates would then embrace accommodating students with SEN as an extension of good teaching practice (DePauw \& Doll - Tepper, 2000; Morley et al, 2005).

\section{Programme content and delivery}

In this study all PETE providers offered core modules in APA in their PE degrees. Across the four institutions, opportunities for undergraduates to gain hands on experience with students with SEN varied, although all programmes provided both theoretical and practical content. Theoretical content was similar across the four providers with practical experience varying from stand-alone modules to SEN related study being accommodated through the degree from second year. Details of programme content and delivery are outlined for each institute.

One institution had a definitive stand alone module of combined theory and practice twice weekly for twelve weeks in year four of 24 hour duration. The theoretical content embraced topics of inclusion, exploration of disabilities and design, enactment and assessment of APA programmes. Practical sessions were based in a local leisure centre with access to a swimming pool, outdoor pitches and an indoor hall. Students worked in groups of five, with five participants with disabilities per group. 
Participants had a variety of SEN/disabilities and ranged in age from children of 8 yrs old to adults of $45 y$ years old. Participants were invited to participate from local schools and disability organisations. Student assessment was based on lesson planning and delivery and completion of reflective practice portfolios. First year PE students also participated in a social mentoring programme with undergraduate student peers with learning disabilities for 2 sessions.

The social mentoring programme is the closest we come to embracing the "infusion" model from the beginning of the degree programme, where it's not ideal it's a start. Our students don't have any input in relation to SEN and PE in second year. In third year we cover "Disability and Youth Health" as a topic in the Health module. In fourth year students complete a semester long module in APA with both theoretical and hands on content. Where both students and participants really enjoy the module, students have to learn about the different disabilities, adaptations and related issues as they run the sessions, which can be difficult. It would be great if the theory could be flowed throw the degree more seamlessly.

Another institution indicated students participated in APA modules in $3^{\text {rd }}$ and $4^{\text {th }}$ year of their degree. In third year students complete 26 theoretical hours examining issues of inclusion, different types of disabilities and different assessment tools. In fourth year students complete a practical semester long module in a variety of disability centres and settings and document their experiences as part of a continuous assessment of the module.

This practical module is held off campus at present under the supervision of staff at the different centres for 12 two hour sessions (total 24 hours). They seem to enjoy the experience overall. They take on planning and running the sessions with support from staff present. I'd like this to take place here at the University sports complex. It's a fantastic setting and would give our participants something to really look forward to; it would also give us a better teaching environment.

A third provider outlined how students gained hands on experience with students with SEN over a semester of 36 hours in the university sports facility. Theoretical content includes differentiation and teaching and learning in PE. For practical sessions, students work in groups of five and design, implement and evaluate APA programmes for students with SEN, over 25 contact hours. Students also document this experience in reflective journals. An end of term exam is also included.

Ideally, I would like if students could gain 'real life' experience of teaching children with SEN in mainstream schools as part of their inclusion module. Given timetabling restraints this is not possible so children with SEN come to the university where students largely work 1:1 with them and although they get invaluable experience, it is not a true reflective experience of when they work in mainstream schools.

The fourth provider outlined a very rich hands on experience offered to students starting in second year and continuing through to the end of $4^{\text {th }}$ year. On this programme students moved through different aspects of APA in disability studies, outdoor activities and adapted physical education from $2^{\text {nd }}$ to fourth year inclusive. Throughout this time students gain both theoretical and practical experience with 96 contact hours in total. These modules include elements both on and off campus. Theoretical content includes inclusive issues, understanding disabilities, lesson planning and adaptation and skill assessment. Practical aspects include lesson planning, implementation and evaluation. Examinations include presentations and written assignments on philosophical issues and analysis of evidenced based practice.

Assessment is also related to improvements by individuals with SEN, feedback from individuals with SEN and their parents, carers, physiotherapists etc. where appropriate is also included. 
No matter how valuable, one special education class or adapted physical education class is not sufficient (Rizzo \& Kirkendall, 1999, Hardin, 2005). Few adapted courses can result in physical educators who have negative attitudes toward including students with disabilities in their programme and in some instances students with disabilities have been excluded from PE classes (Block 1994; Hardin, 2005). From this examination of programme content and delivery great variation exists across the four institutes especially in relation to the amount and manner of time allocated to APA related topics and the practical experience gained at undergraduate levels. The amount of time allocated to APA related study and practice ranged from 29 hours to 96 hours, throughout the degree programmes. Stand alone modules addressing APA are delivered at 2 institutes. This finding was substantiated with the remarks made by a respondent about her efforts to further "infuse" contact and content in relation to SEN issues from the beginning of the degree programme in other modules. However, this is only feasible if those other modules have SEN/Disability related issues embedded in them. The remaining two institutes were more successful in their efforts to include SEN/Disability related topics with specific modules from both second and third years respectively.

According to the European Standards in Adapted Physical Activity (EUSAPA, 2010) the provision of the Irish institute which has 96 hours dedicated to APA and SEN related topics was identified as a European example of good practice. A further example of good practice identified by EUSAPA, is that outlined by Hammer (2010) as practiced in Sweden. Here the National Agency for Special Education in Schools has employed advisors to give support and advice in APA at individual, group and organisational levels. Hammer (2010, p.56) states that

The Authority also cooperates with various universities in courses and training related to APA and organizes and participates in courses, in-service training and conferences.
The delivery of standalone modules in APA arose as an area of concern in the research of Vickerman (2007) in the UK system. This type of delivery serves to identify SEN/Disability related issues as separate entities instead of embracing Wright and Sugden's (1999) view of these issues being an integral part of a PE degree programme "where adaptations are an extension of good practice". Research of Kudlácěk,, Jessina and Flanagan (2010) and Ammah and Hodges (2005) firmly support the infusion of SEN issues throughout $\mathrm{PE}$ degree programmes. However, this would involve a definitive commitment to addressing the issue across individual PE providers and embracing Carey's (2005) view that such commitment in relation to promoting SEN issues in education come from the top down.

\section{Links with schools and mentors; partnerships with disability sport/special needs agencies}

All respondents to this study indicated the importance of establishing meaningful links with schools, community and disability organisations, in ensuring quality $\mathrm{PE}$ is developed and maintained for students with SEN. All respondents looked to experienced teachers, coaches and National Governing Bodies of Sport (NGB) staff with specific qualifications in the field of APA to further the experiences of pre service teachers with students with SEN. On teaching practice, respondents indicated they relied on the support of experienced physical education teachers to ensure pre service students felt adequately supported to accommodate students with SEN in PE classes. One institute indicated having a strong and evolving mentoring programme where pre service teachers are allocated a specific mentor teacher. However, there is no specific emphasis on SEN provision per se; it is only addressed as it arises. In relation to forging links with schools and SEN issues, one respondent indicated her undergraduates facilitated an annual symposium and this year the topic was "Supporting disability and diversity" where secondary school students 
from local schools attend a series of workshops on the topic.

Each respondent indicated that National Governing Body of Sport staff visited each institute to provide workshops in different sports i.e. Irish Wheelchair Sport. Further, three of the four respondents identified using the services of Sports Inclusion Disability Officers (SIDOs) to assist in the delivery of APA modules and to provide "Inclusive Games" training for students. The fourth respondent was not familiar with the role of the SIDO as he was relatively new to working in Ireland. Following the 2005 Adapted Physical Activity conference 'Getting it Right-Including People with Disabilities', a report by the National Disability Authority indicated the urgent need for a coordinated approach to accelerate progress in achieving access, inclusion and quality participation in sport and physical activity (NDA, 2005). In 2008 the CARA Adapted Physical Activity (APA) Centre in conjunction with the local sport partnerships and supported by the Irish Sports Council established the SIDO programme. The stated objectives of the SIDO role include: (a) to increase numbers of people with disabilities participating in sport and physical activity on a regular basis, (b) to support current work of disability sports and physical activity clubs and disability organisations (c) to encourage and support mainstream sports and physical activity clubs in including people with disabilities (O'Reilly \& Crawford, 2009).

One respondent indicated

I wouldn't be able to facilitate our off campus practical sessions without the support of our Sports Inclusion Disability Officer (SIDO) and the Disability Sports Development Officers with the different NGBs. They come along and provide great ideas and practical support during sessions. They also provide us with access to adapted equipment. My students have all established links with $N G B$ representatives and the SIDO so they are able to contact them for help on their teaching practice. They all bring them in to their schools to run disability awareness training, which is great.
Another respondent stated that

I'm really proud of the rounded ethos our students graduate with in relation to inclusion and not being afraid to seek support from NGBs. This type of joined up thinking and using of expertise and resources is what we need.

This openness of all the ITT PE providers to embrace links with schools and disability sports partnerships clearly indicates a commitment to ensure undergraduates experience is as rounded an experience as possible in relation to SEN/Disability issues in APA. In Ireland, "The Best Start Inclusive Schools project" has evolved out of schools visits that the Irish Wheelchair Association (IWA) Sport development team have been conducting around the country since 2007. This programme helps PE teachers to acquire basic competencies needed to successfully teach students with physical disabilities. Bailey (2005) indicated that the forging of the inclusive agenda of ITT collaboration with outside agencies in relation to personnel, equipment and training should be promoted. These findings were reiterated by Crawford (2011) in relation to access to facilities and expertise of National Governing Bodies of Sport for persons with disabilities. Commonalities of inclusive policies and strategies among universities and outside agencies have been identified by other researchers internationally (,Kudlácěk, Jessina \& Flanagan, 2010; Vickerman, 2007; Lambe \& Bones, 2006, Hodge et al., 2004). These include knowledge of ranges of SEN; learning teaching and assessment issues; disability sport partnerships and recognition of policies on inclusion. The importance of celebrating these commonalities and embracing cross organisational expertise in this field further promotes an opportunity for quality programme development and delivery for students with SEN. Further, in a time of economic recession this type of collaboration ensures continuity of programme delivery from Government agencies. 


\section{Values and Attitudes.}

Values and attitudes of each of the respondents were explored across a number of areas to include; accommodation of students with SEN in mainstream schools, preparation of newly qualified teachers to deliver SEN, need for continued professional development for newly qualified teachers, consultation of children with SEN, National PE curriculum and inclusive activities, integration of SEN issues to Teacher training, mixed ability teaching, support and advice of Dept of Education and Skills, professional PE associations and adaptation of $\mathrm{PE}$ in individual Educational Plans.

Accommodation of students with SEN in mainstream schools

All respondents strongly agreed that children with SEN should be accommodated in mainstream settings where feasible.

Of course we should endeavour to ensure students with SEN are accommodated in mainstream schools if they so wish. Research clearly shows us it's great for the student with SEN and it's also great for students without SEN.

This readily embraces the international definition of inclusion in PE as advocated by Block (2007) and further supports the framework document of the Teaching Council (2009) in Ireland.

Preparation of newly qualified teachers to deliver PE to SEN

In relation to preparedness of newly qualified teachers to deliver inclusive activities, two respondents agreed that newly qualified P.E teachers were prepared for delivering inclusive lessons for children with SEN;

I think our students are well prepared for accommodating students with SEN; they're going to have to be creative and stay on top of new diagnosis as they appear.

One respondent disagreed;

I'm not convinced our students are really as prepared as they should be. I find we're trying to cover so much in a limited time, it's what every disability entails.
A fourth respondent strongly disagreed. The latter respondents developed this further on interview:

We have neither time nor resources to ensure our students are properly prepared. This should be an integral part of the programme, instead it's almost an add-on module.

Variance in the views of respondents in relation to the preparedness of newly qualified teachers to deliver PE to students to SEN appears from interview to be associated with the variance in time and practice of SEN/Disability related issues throughout the degree programmes concurring with previous findings (Block, 2007; Smith \& Green, 2004; Vickerman, 2007).

Need for continued professional development for newly qualified teachers

All respondents indicated that newly qualified teachers would need continued professional development programmes. One respondent said

The changes across provision and practice in relation to accommodating students with SEN are constantly evolving internationally. We need to ensure our graduates are up to date with this, so students with SEN get the best possible chance of being included in $P E$ programmes.

Another respondent stated

With the current recession, numbers of Special Needs Assistants (SNAs) in schools are reduced, so our graduates have to be able to adapt more readily to this limitation of support.

Further comments included

Continued professional development is all over the place. Teachers have no idea where to look for this type of quality CPD. PE teachers would be lucky to have an hour of $A P A$ included in their in-service $P E$ provision. I've also noticed the Physical Education Association of Ireland, haven't included any APA workshops or lectures in their annual conferences for the past two years 2010, 2011. 
And

I know from speaking with PE teachers on the ground, they feel like they're really thrown in at the deep end trying to accommodate students with SEN, especially as disabilities in mainstream settings are so varied nowadays, what with limited staff and resources as well.

These findings embrace previous research of Crawford (2011) in the Irish context where primary school teachers expressed a strong desire for ongoing quality APA training with formal qualifications to be made available. An example of good practice in relation to CPD highlighted by EUSAPA (2010) is provided at the Latvian Academy of Sport Education, where detailed in-service teacher education is accommodated in a special school setting over four days, again incorporating theoretical and practical components. In that publication Klavina (2010, p.52) states that

All workshops are provided by experienced specialists with more than 10 years experience working with students with disabilities. Seventy percent of training sessions are practical. Also, the in-service training promotes cooperation between various people in the same field. It is a properplace for exchanging ideas and helping to solve problems. Facilitators indicate that teachers report this approach is particularly effective to their $C P D$.

There is scope for this type of provision to be developed in the Irish context, if the expertise of ITT PE providers is combined with experience of teachers on the ground and embracing further expertise of NGBs of Disability Sport. Despite having identified the lack of in service provision for PE teachers, the PEAI need to take the initiative in this area and support the development and delivery of such programmes to its members in keeping with its identified core value of "inclusivity".

Consultation of children with SEN

All respondents agreed that children with SEN should be consulted in relation to $\mathrm{PE}$ provision.

Quality programmes should include consultation with the students themselves; we all promote concepts of self determination and choice to ensure long term participation in PE programmes. I'm not so sure that the current PE curriculum offers much scope for choice for students with SEN.

And

Yes of course students with SEN should be consulted. I don't think the Dept of Education and Skills are quite ready for hearing the voices of students with SEN though.

Further comments

They are our service users so of course they should be consulted. There's no reason even within the current PE Curriculum structure their voices can't be heard. It's up to us to embed this in our students.

Clearly all respondents believe the voices of students with SEN are integral to quality programme development and participation in APA. This echoes the findings of Fitzgerald, (2005) and Coates and Vickerman,(2010). Further, the voices of our participants with SEN are essential to the principle of self determination as advocated by Reid \& O’Connor (2003) and Crawford, (2007).

National PE curriculum and inclusive activities

Three respondents disagreed that the National PE curriculum provided PE teachers with a clear framework for developing inclusive activities.

There is very little guidance on adaptation of activities I feel. The National PE curriculum is still orientated toward accommodating students without SEN. Little thought is given to peer tutoring, quality buddy programmes, facilities and equipment.

One respondent agreed

I feel the PE curriculum provides definite guidelines; the difficulty arises with $P E$ teachers feeling confident to implement or adapt it.

The statements in relation to lack of a clear framework in the PE curriculum indicates that the Department of Education and Skills together with the National Council for Curriculum Assessment and the Teaching Council need to address a coherent plan to 
provide a clear framework for quality $\mathrm{PE}$ provision for students with SEN. Embracing the "Eight P Inclusive PE Framework" as advocated by Vickerman (2007) would embed the philosophy of inclusion throughout the degree programme. The development of teacher confidence certainly falls within the remit of PETE providers, where Farrell (1998), Dyson (1999) and Vickerman (2007) all share the belief that teachers should be provided with the knowledge and skills to move toward individualised, child centred approaches to education.

Integration of SEN issues to Teacher training and mixed ability teaching

All respondents to the study strongly agreed that SEN issues should be integrated fully into all PE initial teacher training courses and that teaching of children with SEN is just an extension of any PE teachers mixed ability teaching.

Infusing both provision and practice in relation to SEN is essential to the holistic development of our graduates and more importantly to the provision of quality programmes to students with SEN. We shouldn't be isolating this as a topic, rather it should be an integral part of any PE degree programme, embracing Shulman's concept of signature pedagogies within the profession.

These findings concur with those of DePauw and Doll-Tepper (2000) and Morley, Bailey, Tan \& Cook (2005). This further embraces Kudlacek, Jessina and Flanagan's EIPET model (2010) being implemented. The model clearly ensures that knowledge; skills and competencies are developed in the area of sport with inclusion and adapted physical education in mind. Pre service teachers then apply the skills to environments that allow them to develop expertise in working with a range of abilities and disabilities. The transition is completed by marrying the confidence and competencies acquired with the key issues encountered in inclusive physical education. It also echoes Wright and Sugden's (1999) ethos of adaptation being an extension of good practice. $\underline{\text { Support and advice of Dept of Education and }}$ Skills (DES)

In relation to the role of the Department of Education and Skills (DES) offering adequate advice and guidance to $\mathrm{PE}$ institutions on SEN issues, three respondents disagreed, with a fourth respondent strongly disagreeing. Interviews confirmed PETE providers' lack of confidence in the DES;

DES don't care about inclusion in practice, they just pay it lip service.

I feel the DES is not doing enough to support our development and delivery of APA, the inspectorate never contacts us about SEN.

Ironically this is an identified role of the PE Inspectorate (2006). These findings are in direct contrast to those of Vickerman (2007) where teacher trainers indicated that inspection and standards could be overbearing. This lack of support from DES warrants address, as change in relation to SEN provision and practice must come from the top down (Carey, 2005). Further PETE providers need to feel the Department of Education and Skills is accessible to them and supportive of efforts to drive the SEN and Inclusion agenda at undergraduate levels for the future PE teachers of Ireland.

\section{Professional PE Associations}

In relation to the Physical Education Association of Ireland (PEAI), offering adequate advice and guidance to $\mathrm{PE}$ institutions on SEN issues respondents had similar views: two respondents disagreed and two strongly disagreed. Follow up interviews again indicated PETE providers' frustration with the lack of support from their professional organisation in relation to SEN at third level.

I don't have any faith in PEAI addressing SEN issues at third level. I've never had contact from the organisation about SEN and $P E$.

Again as indicated earlier, there is scope for the PEAI to establish strong links with PETE providers in relation to addressing SEN issues given their identified core value of "inclusivity". 
Adaptation of PE in individual Educational $\underline{\text { Plans }}$

In relation to guidelines on individual education plan development under the Education of Person's with Special Educational Needs Act (2004), there were diverging views in that two respondents agreed the IEPs could be related to PE with relative ease while two disagreed.

$I$ think $P E$ teachers can readily adapt their $P E$ teaching to individual educational plans, especially if they work with other experts for example Occupational Therapists, in developing programmes.

Or

Teachers find it difficult to adapt to varying degrees of skill development. I don't think there is enough realistic collaboration in relation to IEP input. As a matter of fact, I'd be very surprised if $\mathrm{PE}$ teachers were consulted at all in the process.

On follow up interview one of the disagreeing respondents stated that as he was relatively new in Ireland he wasn't entirely familiar with current educational policy regarding IEPs and SEN. Anecdotally, PE teachers report not having realistic input to IEPs on the ground. Again the DES is addressing the IEP implementation issue with ongoing training on IEP development and EPSEN Act (2004) information being offered to schools (DES, 2010).

\section{Further comments}

Another area highlighted by all respondents was the need to develop a research agenda both interdepartmentally and across institutions.

I have no idea what is happening in other

institutes in Ireland in relation to research in APA. It's usually just a case of turning up at conferences and meeting colleagues in that context. I keep saying we need to establish inter institutional Communities of Practice in this regard.

And

I would be very keen to see us work together across the four Institutes. I'm sure there are lots of areas we could collaborate on, especially in relation to pre service training and national studies.

This type of collaboration would serve to forge an identity for Ireland in the area of quality APA research, particularly as one of the ITT PE providers has been identified as one implementing good practice in relation to initial teacher training provision in the field (EUSAPA, 2010). This type of collaboration is also a key area to establishing links with other PETE providers internationally. In an effort to address this issue, plans are currently afoot to develop a community of practice across the four ITT PE providers to establish and update on current research practices and programmes.

\section{Limitations of the Study}

A limitation of this study is that of the number of lecturers who contributed. However, as APA continues to develop in Irish PE ITT Institutes this will hopefully be developed in the future. A further limitation is that of concentrating on Ireland. However, it is integral to overall APA development in Physical Education that each country assesses its own provision, practice and experience at third level, to establish the key issues to be addressed and to gain further insight into what can be done to make programmes more successful and meaningful for both participating students with disabilities and for graduates nationally and internationally.

A further study embracing voices of students with SEN, undergraduates of PE programmes and views of Government Departments would enhance findings of this research.

\section{Perspective Paragraph: Conclusions and implications for future practice}

This study highlights variances in the delivery of APA in third level ITT PE providers in Ireland. Key areas to be addressed include; content and practice of APA at undergraduate level, strategic plans and interdepartmental frameworks. A means of addressing issues arising from this study in relation to content and practice at undergraduate level is that of 
adopting the EIPET Model (2010) and infusing it throughout the degree programme, as proposed by De Pauw \& Goc Karp (1994). This further embraces a definite person being allocated to addressing issues of SEN in PE. This ensures consistency of APA content and practice can be guaranteed. Further, a key person could ensure strategic plans embrace the ethos of inclusion and further inform interdepartmental framework development.

Further, ongoing continual professional development should be a must for all newly qualified and experienced teachers to engage with and embrace ongoing developments and changes in the field. Inter institutional collaboration would also support this endeavour, where sharing of ideas of good practice and effectiveness of programme delivery would be commonplace.

Developing of Communities of Practice (Crawford, O'Reilly \& Luttrell, 2011; Harford \& MacRuairc, 2008) in relation to APA would ensure overall quality delivery of programmes to students with SEN. Examples of good practice of ITT PE provision can be embraced nationally. This would also create and develop a research initiative in the area of APA both nationally and internationally.

Strategic plans and Department frameworks should be adapted and clearly indicate a commitment to quality inclusion among PETE providers in Ireland. Embracing Vickerman's (2007) "Eight P Inclusive PE Framework" would ensure Government Departments, Professional Bodies and third level institutions need to be more joined up in their approach to delivering inclusive PE for children with SEN. All have lofty aspirations individually but for meaningful enactment of these principles all relevant legislators and educational bodies need to address the issue of inclusion in Physical Education collaboratively.

\section{REFERENCES}

Ammah, J., \& Hodge, S. (2005). 'Secondary Physical Education Teachers Beliefs and Practices in Teaching Students with
Severe Disabilities: A Descriptive Analysis', The High School Journal, 4, 90-105.

Avramadis, E., \& Norwich, B. (2002). 'Teachers' Attitudes Towards Towards Integration/Inclusion: A Review of the Literature', European Journal of Special Needs Education, 17(2), 129-47.

Bailey, R. (2005). 'Evaluating the Relationship between Physical Educaton, Sport and Social Inclusion', Educational Review, 57(1), 71-90.

Block, M.E. (2007). A Teacher's Guide to Including Students with Disabilities in Gerneral Physical Education. Baltimore, MD, Paul H. Brookes.

Block, M.E., \& Obrusnikova, I. (2007). Inclusion in Physical Education: A Review of the literature from 1995-2005, Adapted Physical Activity Quarterly, 24(2), 103-124.

Blundell, S.W., Shepherd, R.B., \& Dean, C.M. (2003). Functional strength training in cerebral palsy: A pilot study of a group circuit training class for children aged 4-8 years old. Clinical Rehabilitation, 17(1), 48-57.

Carey, D. (2005). The Essential Guide to Special Education in Ireland. Dublin: Primary ABC.

Crawford, S. (2007). Examining the Effects of an Adapted Physical Activity Intervention on the Fundamental Movement Skills and Social Responsiveness of Children with Autism. PhD Thesis, Dept of Physical Education \& Sports Science, University of Limerick, Ireland.

Crawford, S. (2011). An examination of current adapted physical activity provision in primary and special schools in Ireland. European Physical Education Review, 17 (1), 91-109.

Crawford, S., O'Reilly R., \& Luttrell, S. (2011).Assessing the effects of integrating the reflective framework for teaching in physical education (RFTPE) on the teaching and learning of undergraduate sport studies and physical education students, Reflective Practice, 13(1), 115129. 
De Pauw, K.P. \& Goc Karp, G. (1994a). 'Integrating Knowledge of Disability throughout the Physical Activity Education Curriculum: An Infusions Approach', Adapted Physical Activity Quarterly, 11, 1-13.

De Pauw, K.P., \& Doll-Tepper, G. (2000). 'Toward Progressive Inclusion and Acceptance: Myth or Reality? The Inclusion Debate and Bandwagon Discourse', Adapted Physical Activity Quarterly, 17, 135-43.

Denzin, N.K. (1989). The research act: A theoretical introduction to sociological methods (3rd ed.). New Jersey: Prentice Hall.

Department of Education and Science. (1999). Report of the People with a Disability in Sport Taskforce. Dublin: Government Publication Offices.

Department of Education and Skills, (2010). Head Office: Marlborough St, Dublin 1 Retrieved 22.05.12 from www.des.ie.

Department of Education and Skills (2009), Framework Document. Retrieved 22.05.12 from www.teachingcouncil.ie.

Dyson, A. (1999). Examining Issues of Inclusion, (Unpublished Paper). Department of Education, University of Newcastle, U.K.

Department of Education and Science. (1998). Education Act Dublin: Government Publications, Ireland.

Department of Education and Science. (2004). Education for Persons with Disabilities Act Dublin: Government Publications, Ireland.

Department of Education and Science. (2004). Education for Persons with Special Educational Needs Act, Dublin: Government Publications, Ireland.

Department of Education and Science. (2000). Equal Status Act Dublin: Government Publications, Ireland.

Erickson, F. (1986). Qualitative methods in research on teaching. In M.C. Wittrock (Ed.),Handbook of research on teaching (pp. 139-159). New York: Macmillan.

Farrell, M. (1998). The Special Education Handbook. London: David Fulton.
Faison-Hodge, J., \& Porretta, D.L. (2004). Physical activity levels of students with mental retardation and students without disabilities. Adapted Physical Activity Quarterly, 21, 139-152.

Fitzgerald, H. (2005). Still feeling like a spare piece of luggage? Embodied experiences of (dis) ability in PE and school sport . Physical education and sport pedagogy, 10(1).

Folsom-Meek, S.L., \& Nearing, R.J., Groteluschen, W., \& Krampf, H. (1999). Effects of academic major, gender and hands-on experience on attitudes of preservice professionals.Adapted Physical Activity Quarterly, 16, 389-402.

Gita, S., Bognar, J., Kalbli, K., \& Laszlo Dorogi, L. (2008). Comparative study on inclusive and special education curricula in Hungary Physical Education and Sport, $52,16-22$.

Hammar, L. (2010). European Standards in Adapted Physical Activity, First Ed, Palacky University Olomouc, Faculty of Physical Culture.

Hardin, B. (2005). Physical education teachers' reflections on preparation for inclusion. Physical Educator, 62(1), 2341.

Hodge, S.R., \& Jansma, P. (1999). Effects of contact time and location of practicum experiences on attitudes of physical education majors. Adapted Physical Activity Quarterly, 16, 48-63.

Hodge, S.R., Davis, R., Woodward, R., \& Sherrill, C. (2002). Comparison of practicum types in changing preservice teachers' attitude and perceived competence. Adapted Physical Activity Quarterly, 19, 155-171.

Hodge, S., Ammah, O., Casebolt, K., LaMaster, K., \& O'Sullivan, M. (2004). 'High School General Physical Education Teachers Behaviours Associated with inclusion', Sport, Education and Society, 9(3), 395-419.

House of the Oireachtas. (2005). Joint Committee on Education and Science, $3^{\text {rd }}$ Report, The Status of Physical Education. Dublin: Government Press Office, Ireland. 
Hutzler, Y. \& Sherrill, C. (2007). 'Defining Adapted Physical Activity: International Perspectives.' Adapted Physical Activity Quarterly, 24(1), 1-20.

International Federation of Adapted Physical Activity. (2004). Cited in Y. Hutzler \& C. Sherrill (2007). 'Defining Adapted Physical Activity: International Perspectives.' Adapted Physical Activity Quarterly, 24(1), 1-20.

Ito, C. (1999). 'Inclusion Confusion', Retrieved 22.05.12 from http://education .wm.edu/centers/ttac/resources/articles/inc lusion/inclusconfuse/index.php

Klavina, A., Block, M., \& Larins, V. (2007). General physical educators' perceptions of including students with disabilities in general physical education in Latvia. Palaestra, 23(3).

National Council for Curriculum and Assessment/Department of Education and Science. (2003). Junior Cycle Physical Education, Government of Ireland.

Kozub, F.M., Sherblom, P.R., \& Perry, T.L. (1999). Inclusion paradigms and perspectives: A stepping stone to accepting learner diversity in physical education. Adapted Physical Activity Quarterly, 51, 346-354.

Kudláček, M., Jesina, O., Flanagan, P. (2010). 'European Inclusive Physical Education Training.' Advances in Rehabilitation, 3, 14-17.

Kudláček, M., Morgulec-Adamowicz, N., \& Verellen (2010). European Standards in Adapted Physical Activities.Published and printed by Palacký University Olomouc.

Kvale, S., \& Brinkmann, S. (2009). Interviews: Learning the Craft of Qualitative Research Interviewing (2 ${ }^{\text {nd }}$ Edition), 353-354, Thousand Oaks. CA.

LaMaster, K., Gall, K., Kinchin, G., \& Siedentop, D. (1998). Inclusion practices of effective elementary specialists. Adapted Physical Activity Quarterly, 15, 64-81.

Lambe, J., \& Bones, R. (2006). 'Student Teachers Attitudes to Inclusion: Implications for initial Teacher Education in Northern Ireland', International Journal of Inclusive Education, 10(6), 511-27.
Lieberman, LJ., Dunn, J., van der Mars, H., \& McCubbin, J. (2000). Peer tutors' effects on activity levels of deaf students in inclusive elementary physical education. Adapted Physical Activity Quarterly, 17, 20-39.

Lienert, C., Sherrill, C., \& Myers, B. (2001). Physical educators' concerns about integration children with disabilities: A cross-cultural comparison. Adapted Physical Activity Quarterly, 18, 1-17.

Meegan, S., \& MacPhail, A. (2006). Irish physical educators' attitude toward teaching students with special educational needs. European Physical Education Review, 12(1), 75-97.

Morley, D., Bailey, R., Tan, J., \& Cooke, B. (2005). 'Inclusive Physical Education: Teachers' Views of Including Pupils with Special Educational Needs and/or Disabilities in Physical Education', European Physical Education Review, 11, 84-107.

National Council for Curriculum and Assessment. (1999). Special Educational Needs: Curriculum Issues: Discussion Paper. Dublin: Government of Ireland.

National Disability Authority. (2005).

Promoting the participation of people with disabilities in physical activity and sport in Ireland; Government of Ireland

Publications, Ireland.

O'Reilly, R., \& Crawford, S., (2009). The Newly Appointed Sports Inclusion Disability Officer - Delivering Sport and Physical Activity to Individuals with Disabilities in Ireland. Advances in Rehabilitation, 14(3), 22-34.

Pate, R.R., Davis, M.G., Robinson, T.N., Stone, E.J., McKenzie, T.L., \& Young, J.C. (2006). Promoting physical activity in children and youth: A leadership role for schools. Circulation, 114, 1214-1224.

Reid, G., O'Connor, J., \& Lloyd, M. (2003). The autistic spectrum disorders: Physical activity instruction - part III. Palaestra, 19(2), 20-26, 47-48.

Sallis, J.F., Conway, T.L., Prochaska, J.J., McKenzie, T.L., Marshall, S.J., \& Brown, M. (2001). The associations of school environments with youth physical activity. 
American Journal of Public Health, 91, 618-620.

Sherrill, C. (1998). 'Adapted Physical Activity, Recreation and Sport: Crossdisciplinary and Lifespan. Fifth Edition.' Boston, Mass: WCB/McGrawHill.

Shevlin, M., \& O'Moore, A.M., (2000). Creating opportunities for contact between mainstream pupils and their counterparts with learning disabilities. British Journal of Special Education, 27(1).

Smith, A., \& Green, K. (2004). 'Including Pupils with Special Educational Needs in Secondary School Physical Education: A Sociological Analysis of Teachers Views', British Journal of Sociology of Education, 25(5), 594-607.

Special Education Review Committee (SERC) Report. (1993). Dublin: Government Publications.

The Report of the Government Commission on the Status of People with Disabilities. (1996). Dublin: Government Publications, Ireland.

The Teaching Council. (2007). Codes of Professional Conduct for Teachers Teaching Council, Kildare, Ireland.

The Teaching Council. (2009). Teaching Council [Registration] Regulations Teaching Council Kildare, Ireland.

The World Health Organisation. (2004). Benefits of Physical Activity. Retrieved 22.05.12.

from.http//www.who.int/movefor

health/advocacy/information-

sheets/benefits/en/index.html.

United Nations. (1989). Convention on the Rights of the Child. Office of the United Nations, New York.
United Nations. (1993). Standard Rules on the Equalisation of Opportunities for Persons with Disabilities. Office of the United Nations, NY.

United Nations Educational, Scientific and Cultural Organizations. (1994). The Salamanca Statement and Framework for Action. Paris: UNESCO.

Vickerman, P. (2004). The training of Physical Education Teachers for the Inclusion of Children with Special Educational Needs: PhD Thesis, School of Education, University of Leeds, Leeds, U.K.

Vickerman, P. (2007). Teaching Physical Education to Children with Special Educational Needs. London: Routledge.

Vickerman, P. \& Coates, J.K. (2009). Trainee and recently qualified teachers' perspectives on including students with special educational needs. Physical Education and Sport Pedagogy, 14(2), 137-153.

Winnick, J.P. (2005). Adapted Physical Education and Sport. Champaign,Illinois: Human Kinetics.

Wright, H., \& Sugden, D. (1999). Physical Education for All: Developing Physical Educatoin in the Curriculum for Pupils with Special Educational Needs. London: David Fulton.

Xafopoulos, G., Kudláček, M., \& Evaggelinou, C., (2009). Effect of the intervention program "paralympic school day" on attitudes of children attending international school towards inclusion of students with disabilities. Acta Universitatis Palackianae Olomucensis, 39(4).

Corresponding author's e-mail address: s.crawford@ucc.ie

(Abstract)

UNTERSUCHUNG DES AKTUELLEN ANGEBOTS, DER PRAXIS UND DER ERFAHRUNG DER LEHRERINNENAUSBILDENDEN IN IR LAND, DIE DIE ZUKÜNFTIGEN LEHRPERSONEN FÜR DIE INKLUSION VON SCHÜLER/INNEN MIT 


\section{BESONDEREM PÄDAGOGISCHEN FÖRDERBEDARF IM SPORTUNTERRICHT VORBEREITEN}

Die Forschung aus einer internationalen Perspektive in Bezug auf die Vorbereitung von Lehramtsstudierende für Bewegungs- und Sondererziehung zeigt, dass deren Ausbildung inkonsistent ist, was das Zeitausmaß betrifft, das für die Behandlung dieser Thematik und die Inhalte des Lehrplans aufgewendet wird (Vickerman, 2007). In Irland bestätigen die Forschungen von Meegan \& MacPhail (2005) und Crawford (2011) dass Sportlehrende sich nicht ausreichend vorbereitet fühlen für die Aufnahme von Schüler/innen mit sonderpädagogischem Förderbedarf (SEN). Es wurden qualitative Methoden verwendet, die Fragebogen und Interviews $(n=4)$ umfassten. Die Ergebnisse zeigten, dass es im zeitlichen Umfang (Module für ein Semester), in dem mit Kindern mit Behinderung in Mainstream Settings (Schule oder Freizeitbereich) gearbeitet wird, ein Mangel an Zusammenarbeit mit anderen Sportlehrer-Ausbildenden $(n=4)$ besteht und der Bedarf an fortlaufender professioneller Weiterbildung als hervorzuhebendes Thema bezeichnet wurde. Es wird vorgeschlagen, einen kombinierten Zugang zu verwenden, wobei das kürzlich entwickelte Modell des ,European Inclusive Physical Education Trainings ‘ - EIPET (Kudlácěk, Jesina, \& Flanagan, 2010) im Undergraduate-Programm eingebracht werden sollte. Weiters erscheint es wichtig, aktiv eingreifende Praxiserfahrung für Undergraduates in Mainstream Settings einzuführen und inter-institutionelle Praxisgemeinschaften mit einer nationalen Initiative für Studien zu Behinderung zu etablieren. All das gilt es zu unternehmen um qualitativ hochwertige Ausbildung und Training in adapted physical activity in ganz Irland zu garantieren.

Schlüsselwörte: Lehrer/innen-Ausbildung, Bewegungserziehung, Sonderpädagogischer Förderbedarf, Inklusion

(Аннотацця)

\section{ИССЛЕДОВАНИЕ СУЩЕСТВУЮЩИХ ПОЛОЖЕНИЙ, ПРАКТИК И ОПЫТА НАЧАЛЬНОЙ ПОДГОТОВКИ УЧИТЕЛЕЙ В ИРЛАНДСКОЙ ПОДГОТОВКЕ УЧИТЕЛЕЙ СЕРВИСА ДЛЯ ВКЛЮЧЕНИЯ УЧАЩИХСЯ С ОСОБЫМИ ОБРАЗОВАТЕЛЬНЫМИ ПОТРЕБНОСТЯМИ В УРОКИ ФИЗКУЛЬТУРЫ}

Международные исследования о включении учащихся со специальными образовательными потребностями в процесс физического воспитания показывают, что начальная подготовка учителей непоследовательна в количестве времени, затраченного на рассмотрение вопроса и характер содержания учебных программ (Vickerman, 2007). В Ирландии, исследования Meegan и MacPhail (2005) и Кроуфорд (2011) указывают, что преподаватели физического воспитания не чувствуют себя надлежащим образом подготовленными для включения учащихся с особыми образовательными потребностями (СООП) в уроки физкультуры. Это исследование изучило начальную подготовку учителей в Ирландии. Методика была качественная и включала опросники и интервью $(\mathrm{n}=4)$. Результаты показали распределение времени (семестры) для работы с детьми с ограниченными возможностями в общеобразовательных заведениях (школа или центр досуга), отсутствие сотрудничества с другими специалистами $(п=4)$ и необходимость постоянного профессионального развития. 
Было предложено использование комплексного подхода, разработанного Европейской Подготовкой Кадров в области Инклюзивной Физической Культуры (Kudlácěk, Jesina, \& Flanagan, 2010). Кроме того, использование практического опыта для таких учащихся в общеобразовательных заведениях и создание межрегиональных институциональных сообществ с национальной инициативой исследования инвалидности, имеет важное значение для обеспечения качества адаптированной физической подготовки по всей Ирландии.

Ключевые слова: начальная подготовка учителей, физическое воспитание, особые образовательные потребности, включение

(Resumen)

\section{EXAMINANDO LA ACTUAL PROVISIÓN, PRÁCTICA Y EXPERIENCIA DE LOS PROVEEDORES DE FORMACIÓN INICIAL DEL PROFESORADO EN IRLANDA EN LA PREPARACIÓN DE PROFESORES PARA LA INCLUSIÓN DE ESTUDIANTES CON NECESIDADES EDUCATIVAS ESPECIALES EN LAS CLASES DE EDUCACIÓN FÍSICA}

La investigación desde una perspectiva internacional en relación con la preparación de profesores de educación física y las necesidades educativas especiales indica que los proveedores iniciales de formación del profesorado no tienen definida la cantidad de tiempo dedicado a tratar el tema y la naturaleza del contenido curricular (Vickerman, 2007). En Irlanda, la investigación de MeeGo y MacPhail (2005) y Crawford (2011) indica que los profesores de educación física no se sienten suficientemente preparados para dar cabida a los alumnos con necesidades educativas especiales (NEE) en las clases de educación física. Este estudio examinó la provisión inicial de formación docente en Irlanda en la formación de profesores de educación física previa al servicio en el SEN. La metodología utilizada fue cualitativa e incluyeron cuestionarios y entrevistas $(n=4)$. Los resultados indicaron que la distribución del tiempo (módulos semestrales) en los que se trabaja con niños con discapacidad en centros ordinarios (escuela o centro de ocio), la falta de colaboración con otros proveedores de Educación Física $(n=4)$ y la necesidad de desarrollo profesional continuo, fueron temas que necesitan ser tratados y analizados. Se propone el uso de un enfoque combinado en el que se propone la inclusión en los programas de formación de licenciatura el recientemente diseñado programa Formación Europea en Educación Física Inclusiva (Kudláček, Jesina, \& Flanagan, 2010). Además, la búsqueda de experiencias directas de los estudiantes en los centros ordinarios y el establecimiento de relaciones institucionales con comunidades de práctica, con una iniciativa nacional de investigación en discapacidad, es esencial para garantizar la calidad de formación en actividad física adaptada que puede tener cabida en toda Irlanda.

Palabras clave: formación inicial del profesorado, educación física, necesidades educativas especiales, Inclusión.

(Resumo) 


\section{EXAMINANDO O FORNECIMENTO ACTUAL, A PRÁTICA E A EXPERIÊNCIA DOS RESPONSÁVEIS PELA FORMAÇÃO INICIAL DE PROFESSORES NA IRLANDA, NA PREPARAÇÃO INICIAL DE PROFESSORES PARA A INCLUSÃO DE ESTUDANTES COM NECESSIDADES EDUCATIVAS ESPECIAIS NAS AULAS DE EDUCAÇÃO FÍSICA}

A pesquisa de uma perspectiva internacional em relação à preparação inicial de professores em educação física e em necessidades educativas especiais indicia que os responsáveis pela formação inicial de professores são inconsistentes quanto ao período de tempo gasto na apresentação do assunto e a natureza do conteúdo curricular (Vickerman, 2007). Na Irlanda, estudos realizados Meegan e MacPhail (2005) e Crawford (2011) demonstram que os professores de educação física não se sentem convenientemente preparados para receber estudantes com necessidades educativas especiais (NEE) nas aulas de educação física. Este estudo examinou a influência do fornecimento e da formação inicial de professores na Irlanda na formação inicial dos professores de educação física em NEE. A metodologia utilizada foi de natureza qualitativa e incluiu questionários e entrevistas $(\mathrm{n}=4)$. Os resultados demonstraram que o tempo atribuído (módulos ao longo do semestre), o trabalho com crianças com deficiência ao nível comunitário (escolas regulares ou centros de laser) a falta de colaboração com outros fornecedores PETE $(n=4)$ e a necessidade de um desenvolvimento profissional contínuo foram temas tidos como de análise necessária. Utilizando uma abordagem combinada onde a recém-criado Modelo Europeu de Formação em Educação Física Inclusiva (Kudlácěk, Jesina, \& Flanagan, 2010) é infundido através da proposta de um programa prégraduado. Mais, a acomodação de mãos na experiência para estudantes universitários em escolas regulares e o estabelecimento de comunidades interinstitucionais de prática, com uma iniciativa nacional de pesquisa na deficiência, é essencial para garantir que a qualidade da formação em actividade física adaptada pode ser acomodado em toda a Irlanda.

Palavras-Chave: Formação inicial de professores, educação física, Necessidades Educativas Especiais, Inclusão 